\title{
Hepatocyte growth factor and chronic hepatitis C
}

\author{
E. Marín-Serrano ${ }^{1}$, C. Rodríguez-Ramos ${ }^{1}$, F. Díaz-García ${ }^{1}$, L. Martín-Herrera ${ }^{1}$, C. Fernández-Gutiérrez- \\ del-Álamo² and J. A. Girón-González ${ }^{3}$
}

Services of ${ }^{1}$ Digestive Diseases, ${ }^{2}$ Microbiology, and ${ }^{3}$ Internal Medicine. Hospital Universitario Puerta del Mar. Cádiz, Spain

\begin{abstract}
Objective: the hepatocyte growth factor (HGF) is a pleiotropic cytokine produced by hepatic stellate cells and implicated in liver regeneration and fibrosis. Serum levels of HGF vary in liver diseases, reflecting hepatic damage and hepatocellular dysfunction. In this study, serum levels of HGF and the relationship between HGF and biochemical, histological and virological data, have been analysed in patients suffering from chronic hepatitis $\mathrm{C}(\mathrm{CHC})$.

Patients and methods: serum HGF concentration was measured by ELISA in sandwich in 45 patients with $\mathrm{CHC}$. Correlation between HGF levels and histological (necroinflammatory activity and fibrosis score) and biochemical (transaminases, prothrombin activity, albumin, bilirubin), or virological (hepatitis C virus load) parameters was analyzed. Serum HGF concentration was also studied in a subgroup of the original sample treated with interferon and ribavirin.

Results: serum HGF concentrations of patients with $\mathrm{CHC}$ were significantly higher than those detected in healthy controls. Patients with significant fibrosis $(F \geq 2)$ had a significantly older age, lower count of platelets and higher values of AST, GGT and HGF, than those patients with a fibrosis score $\mathrm{F}<2$. HGF concentration was identified by multivariate analysis as the only independent factor associated with significant fibrosis. Moreover, area under receiver operating curve, using HCG levels, showed similar values to those of previously validated non-invasive indexes of fibrosis. However, levels of HGF did not show a significant decrease in patients with a sustained response to anti-virus $\mathrm{C}$ therapy.

Conclusion: serum HGF concentration correlates with fibrosis score in patients with $\mathrm{CHC}$, but is insensitive to monitor changes induced by anti-virus $\mathrm{C}$ therapy.
\end{abstract}

Key words: Chronic hepatitis C. Liver fibrosis. Hepatocyte growth factor (HGF).

Received: $13-10-09$

Accepted: 22-01-10

Correspondence: Eva Marín-Serrano. Servicio de Aparato Digestivo. Hospital Universitario Puerta del Mar. Avda. Ana de Viya, 21. 11009 Cádiz, Spain.e-mail: evamarins@hotmail.com

\section{RESUMEN}

Objetivo: el factor de crecimiento hepatocitario (HGF) es una citocina pleiotrópica producida por las células estrelladas hepáticas, que está implicada en la regeneración y la fibrosis hepática. La concentración sérica del HGF en las enfermedades hepáticas es variable, reflejando daño hepático y disfunción hepatocelular. En este estudio se ha analizado la concentración sérica del HGF en pacientes con hepatitis crónica por virus de la hepatitis $\mathrm{C}(\mathrm{VHC})$ y su relación con los datos bioquímicos, histológicos y virológicos.

Pacientes y métodos: se determinó la concentración sérica de HGF mediante ELISA en sándwich y se analizó la correlación entre los niveles del HGF y los datos histológicos (actividad necroinflamatoria, estadio de fibrosis), bioquímicos (transaminasas, actividad de protrombina, albúmina, bilirrubina) y virológicos (carga viral VHC) en 45 pacientes con hepatitis crónica C (HCC). También fueron evaluadas las cifras del HGF en el suero de un subgrupo de pacientes de la muestra original sometidos a tratamiento antiviral con interferón y ribavirina.

Resultados: la concentración sérica del HGF en pacientes con HCC fue significativamente mayor que la medida en controles sanos. Los pacientes con fibrosis hepática significativa $(F \geq 2)$ tenían una edad significativamente mayor, unas cifras plaquetarias significativamente inferiores y concentraciones séricas significativamente superiores de AST, GGT y HGF, en comparación con aquellos pacientes con un índice de fibrosis $\mathrm{F}<2$. En el análisis multivariante la concentración de HGF fue la única variable independiente asociada a la fibrosis significativa. El área bajo la curva ROC (receiver operating curve), usando las concentraciones séricas de HGF, mostró valores similares a los obtenidos con otros índices, previamente validados, que estiman fibrosis significativa en pacientes con HCC. Sin embargo, las cifras del HGF no descendieron de modo significativo en aquellos pacientes con respuesta sostenida a tratamiento antiviral.

Conclusión: la concentración sérica del HGF se correlaciona con el índice de fibrosis en pacientes con HCC, pero es un marcador poco sensible para monitorizar la respuesta inducida por el tratamiento antiviral.

Palabras clave: Hepatitis crónica C. Fibrosis hepática. Factor de crecimiento hepatocitario (HGF).

Marín-Serrano E, Rodríguez-Ramos C, Díaz-García F, MartínHerrera L, Fernández-Gutiérrez-del-Álamo C, Girón, González JA. Hepatocyte growth factor and chronic hepatitis C. Rev Esp Enferm Dig 2010; 102: 365-371. 


\section{INTRODUCTION}

Inflammation, apoptosis and the specific immune response are essential for a proper antiviral host defence (1). However, an uncontrolled inflammatory response is the common mechanism involved in the majority of clinical liver pathologies, resulting in tissue damage and fibrosis (2). In fact, acute inflammatory reaction provokes, on the one hand, necrotic or apoptotic cells that the hepatocytes are able to regenerate and replace and, on the other hand, a limited deposition of extracellular matrix (ECM). Nevertheless, should the insult persists, liver regeneration fails and hepatocytes are replaced with abundant ECM proteins forming the hepatic scar (3-5).

Liver regeneration is a process with at least two critical steps: the transition of the quiescent hepatocyte into the cell cycle (priming) and the progression beyond the restriction point in the G1 phase of the cycle. It has been proposed that these steps are under separate control, priming by tumour necrosis factor alpha and interleukin-6 family cytokines, and cell cycle progression by the growth factors, mainly by hepatocyte growth factor (HGF) $(6,7)$.

The morbimortality of patients suffering from chronic hepatitis $\mathrm{C}$ (HCC) is manifested by the development of liver fibrosis and the subsequent occurrence of cirrhosis and its complications (8).

HGF is a cytokine with a glycoprotein nature produced by mesenchymal cells of different organs, among them the liver, implicated in hepatic regeneration (9) and considered a prognosis factor in liver diseases, such us CHC. This is due to its correlation with liver damage and dysfunction, as well as its usefulness as tumour marker for diagnosis of hepatocellular carcinoma (10-12). Serum HGF levels vary in liver diseases, but have exhibited a negative correlation with albumin concentration and prothrombin time in cirrhotic patients; individuals with Child class $\mathrm{C}$ had higher levels of serum HGF than those graded as Child class A or B (13-15).

In this study, serum levels of HGF have been analysed in patients with $\mathrm{CHC}$ with the objective of evaluating the interrelationship between HGF and histological (necroinflammatory activity and fibrosis score), biochemical (transaminases, albumin, bilirubin and prothrombin activity) and virological (hepatitis $\mathrm{C}$ virus load) data. Given that serum HGF concentrations could reflect the repairing mechanisms indissolubly associated to liver injury, HGF levels have been also studied in a subgroup of the original sample treated with interferon and ribavirin, assuming that if the pathogen is eliminated, a down-regulation of $\mathrm{HGF}$ would be detected.

\section{PATIENTS AND METHODS}

\section{Patients and controls}

Forty-five patients with $\mathrm{CHC}$ attended at the Gastroenterology Unit of the Hospital Universitario Puerta del Mar, Cádiz, Spain, have been included in this study.
Inclusion criteria were the following: a) HCV (hepatitis $\mathrm{C}$ virus) infection (defined as a positive serology result by a second or third generation enzyme-linked immunosorbent assay and a positive result from a polymerase chain reaction test); b) increase in the serum aminotransferase levels for at least 6 months; and c) an interpretable liver biopsy in the last 6 months.

Exclusion criteria were the following: a) positivity of hepatitis B surface antigen; b) antibodies against antihuman immunodeficiency virus; c) other infectious, autoimmune, tumoral, biliary, or vascular-associated liver disease; d) active alcohol or drug dependence; e) clinical or biochemical criteria of decompensated cirrhosis; f) clinical evidence of infection, including spontaneous bacterial peritonitis; g) treatments, which could have modified the determination of HGF (steroidal or nonsteroidal anti-inflammatory or immunosuppressive drugs); and h) red blood cell or plasma transfusion in the month prior to inclusion in the study. These were not allowed in order to rule out the possible interference of contamination or reactions between these elements and the inflammatory and immune system of the receptor.

Fifteen healthy controls were selected from hospital workers; the absence of evidence of infection was confirmed by clinical history, physical exploration and laboratory tests. Informed consent was obtained from patients and controls. The protocol conformed to the ethical guidelines of the 1975 Declaration of Helsinki and had been approved by the institutional human research committee.

\section{Anti-HCV treatment protocol}

Indications for interferon alpha plus ribavirin therapy were based on individual clinical, histological, and virological status, according to consensus recommendation at the time of patient inclusion $(16,17)$. A minimum fibrosis score $>1$ was needed to indicate the antiviral therapy.

Exclusion criteria related with the treatment with interferon and ribavirin, include: a) previous interferon or ribavirin therapy; b) a Karnofsky index $<80$; c) absolute counts of neutrophils at $<1,500$ cells/ $\mu$ l, platelets at $<90,000$ cells $/ \mu$ or haemoglobin concentration at $<11.0 \mathrm{~g} / \mathrm{dl}$; d) haemolytic conditions; e) poorly controlled psychiatric disease; f) substantial coexisting medical conditions (heart failure, respiratory insufficiency, kidney failure, autoimmune conditions, epilepsy, retinopathy, and previous organ transplant); g) gestation or lactation; and h) inability to use contraceptive measures.

Twenty-five patients received combination therapy. The standard duration of treatment was 48 weeks for genotype 1-4 and 24 weeks for genotypes 2-3. Daily dose of ribavirin was $800 \mathrm{mg}$ in genotype 2-3 and depending on body weight $(1,000-1,200 \mathrm{mg})$ in geno- 
type 1-4. Patients were followed during therapy by visits at weeks $0,2,4,6,8,12,24,48$ and 72 . At each visit was made a clinical, laboratory and therapy monitoring, to assess the response to treatment, occurrence of side effects or need to reduce or to stop the treatment. HCVRNA load were performed at week 12 of treatment in patients with genotype 1-4; treatment was discontinued in those who did not achieve an early virological response $(\mathrm{EVR} ;>2 \mathrm{log}$ reduction in HCV-RNA). Determinations of HCV-RNA load were tested after stopping treatment, and if was negative, at the end of follow-up too.

The criteria for interruption of the study were: a) concurrent disease that required the use of immunosuppressive therapy; b) decision of the patient to discontinue the treatment; and c) patients with genotype 1-4 who did not achieve a reduction more than $2 \mathrm{log}$ in $\mathrm{HCV}$ RNA at $12^{\text {th }}$ week of treatment.

According to the response to treatment, patients were classified in three groups: a) non-responders, patients who did not achieve a reduction more than $2 \log$ reduction in HCV-RNA at $12^{\text {th }}$ week of treatment or who remained a positive HCV viral load at the end of treatment; b) sustained responders, those with a negative $\mathrm{HCV}$ viral load at the end of the therapy and continued to be negative 6 months after the end of treatment; and c) relapsers, when the patients negativized HCV load at the end of the therapy but showed a positive HCV viral load 6 months after stopping treatment.

HGF serum levels were measured at baseline, at the end of therapy and, in responders, six months after the end of treatment.

\section{Laboratory determinations and histological evaluation}

Haemogram, blood sugar, renal and liver function, lactate dehydrogenase, total proteins, albumin, cholesterol, triglycerides, uric acid, alpha 1-antitrypsin, ceruloplasmin, porphyrin, auto antibodies (ANA, AMA, SMA, LKM, TPO and thyroglobin), thyroid hormones, iron metabolism, prothrombin and anti-HAV, HBV and HIV serology, were performed by automated tests in the laboratory located at Hospital Universitario Puerta del Mar.

Serum of all patients was reactive for anti-HCV by both a third-generation enzyme immunoassay (EIA-3) (Ortho Diagnostic System, Raritan, NJ, USA) and a second-generation recombinant immunoblot assay (RIBA2) (Ortho Diagnostic System, Raritan, NJ, USA). Plasma samples were tested for HCV RNA by reverse transcription-polymerase chain reaction (Amplicor $\mathrm{HCV}$, Roche Diagnostics, Basle, Switzerland). HCV genotypes were determined by line probe assay (INNOLiPA HCV; Innogenetics, Antwerp, Belgium).
Blood samples of healthy controls and patients were collected in sterile Vacutainer tubes (Becton-Dickinson Vacutainer System, Meylan Cedex, France) and centrifuged $\left(3,500 \mathrm{rpm}\right.$ for $15 \mathrm{~min}$ at $\left.4{ }^{\circ} \mathrm{C}\right)$. Serum was stored within four hours at $-80{ }^{\circ} \mathrm{C}$ in pyrogen-free polyethylene tubes (Biofreeze, Costar, USA) until HGF was assayed with ELISA kits (R \& D, Minneapolis, USA), according to manufacturer's instructions, with a detection limit (lowest positive standard) of $40 \mathrm{pg} / \mathrm{ml}$.

Liver biopsies, measuring more than $10 \mathrm{~mm}$ in length, were fixed, paraffin-embedded, and stained with haematoxylin-eosin safran and Masson's trichrome. The one same experienced pathologist who was not aware of the clinical or biological data assessed all the biopsies. For each liver biopsy, a numerical score was established to evaluate the degree of necroinflammatory activity and stage of fibrosis, using the index of histological activity proposed by Knodell (18) and modified by Scheuer and Desmet (19).

\section{Predictive indexes of fibrosis}

Several authors have validated models to predict the severity of liver fibrosis by non-invasive means. Some of them rely on routine laboratory tests, easily available in clinical practice. Among the indexes based on routinely available laboratory tests, we selected two of them with internal and external validation $(20,21)$. These indexes were elaborated with the aim of discriminating significant fibrosis $(\mathrm{F} \geq 2)$. The index by Forns et al. is calculated applying the following regression equation:

\subsection{1-3.131 ln (platelet count, $\left.10^{9} / \mathrm{L}\right)+0.781 \ln (G G T$, $U I / L)+3.467 \ln ($ age, years $)-0.014$ (cholesterol, $\mathrm{mg} / \mathrm{dL}$ ).}

The index by Wai et al., known as AST platelet ratio index (APRI), is calculated by dividing the AST level (UI/L) expressed as the number of times above the upper limit of normal ULN by the platelet count $\left(10^{9} / \mathrm{L}\right)$ :

$$
\text { AST (/ULN) × 100/Platelet count }\left(10^{9} / \mathrm{L}\right) .
$$

\section{Statistical analysis}

Quantitative variables are presented as median and $95 \%$ confidence interval (95\% CI) from de media, and qualitative variables as absolute number and percentage. Qualitative variables were compared using Chi-square or Fisher's exact test. The data from two independent groups were compared with the Mann-Whitney U test. Significance of parameters within each group was tested by the Wilcoxon matched-pairs signed rank test. Correlations were assessed by the Spearman's method. 
The relationship of biochemical variables with liver fibrosis was assessed. The independent variables with a possible association were evaluated via stepwise logistic regression; a fibrosis score $>2$ was the dependent variable. The diagnostic value of the model was assessed by measuring the areas under the receiver operating characteristic curves (AUROC).

A p value lower than 0.05 was considered significant. The statistical analysis was performed using the SSPS 11.5 program (SPSS Inc, Chicago, Illinois, USA).

\section{RESULTS}

\section{Baseline characteristics}

Demographic, virologic and histologic characteristics of patients with CHC are shown in table I. Baseline concentrations of HGF in patients were significantly higher than that detected in healthy controls [3.08 (3.01-3.15) vs. 2.73 (2.55-2.87) Log pg/ml, $\mathrm{p}<0.001]$.

Serum concentration of $\mathrm{HGF}$ in patients with $\mathrm{CHC}$ was positively correlated with the following variables: age $(r=0.37, p=0.013)$, AST $(r=0.51, p=0.000)$, ALT $(r=0.36, p=0.015)$, gammaglutamyltranspepti- dasa $(\mathrm{GGT})(\mathrm{r}=0.48, \mathrm{p}=0.001)$ and fibrosis score $(\mathrm{r}=$ $0.55, \mathrm{p}=0.000)$. However, a significant correlation with HCV load $(r=-0.04, p=0.799)$, necroinflammatory activity $(\mathrm{r}=0.20, \mathrm{p}=0.211)$, or parameters related with liver failure, such as serum bilirubin $(\mathrm{r}=-0.12, \mathrm{p}=$ $0.432)$, albumin $(\mathrm{r}=-0.11, \mathrm{p}=0.478)$ or prothrombin activity $(\mathrm{r}=0.02, \mathrm{p}=0.907)$, was not obtained.

Chronic hepatitis patients were divided in two groups according to the presence of clinically significant fibrosis (patients with $F<2$ and $F \geq 2$ ). Patients with significant fibrosis $(F \geq 2)$ had a significantly older age, lower count of platelets and higher values of AST, GGT and $\mathrm{HGF}$, than those patients with a fibrosis score $\mathrm{F}<2$. HGF concentration was identified by multivariate analysis as the only independent factor associated with significant fibrosis. Multivariate analysis showed that only serum HGF had an independent association with clinically significant fibrosis (Table I). Serum concentrations of HGF in each one of the fibrosis stages is shown in figure 1 .

Next, we analysed the ability of non-invasive fibrosis indexes to predict liver fibrosis in our sample. The AUROC for the Forns et al. and the Wai et al. models, as well as that based in serum HGF concentrations, were similar $(0,769,0,779$ and 0,759 , respectively) (Fig. 2).

Table I. Demographic, biochemical, virological and histological characteristics of the patients with chronic hepatitis $C_{\text {, grouped }}$ according fibrosis stage

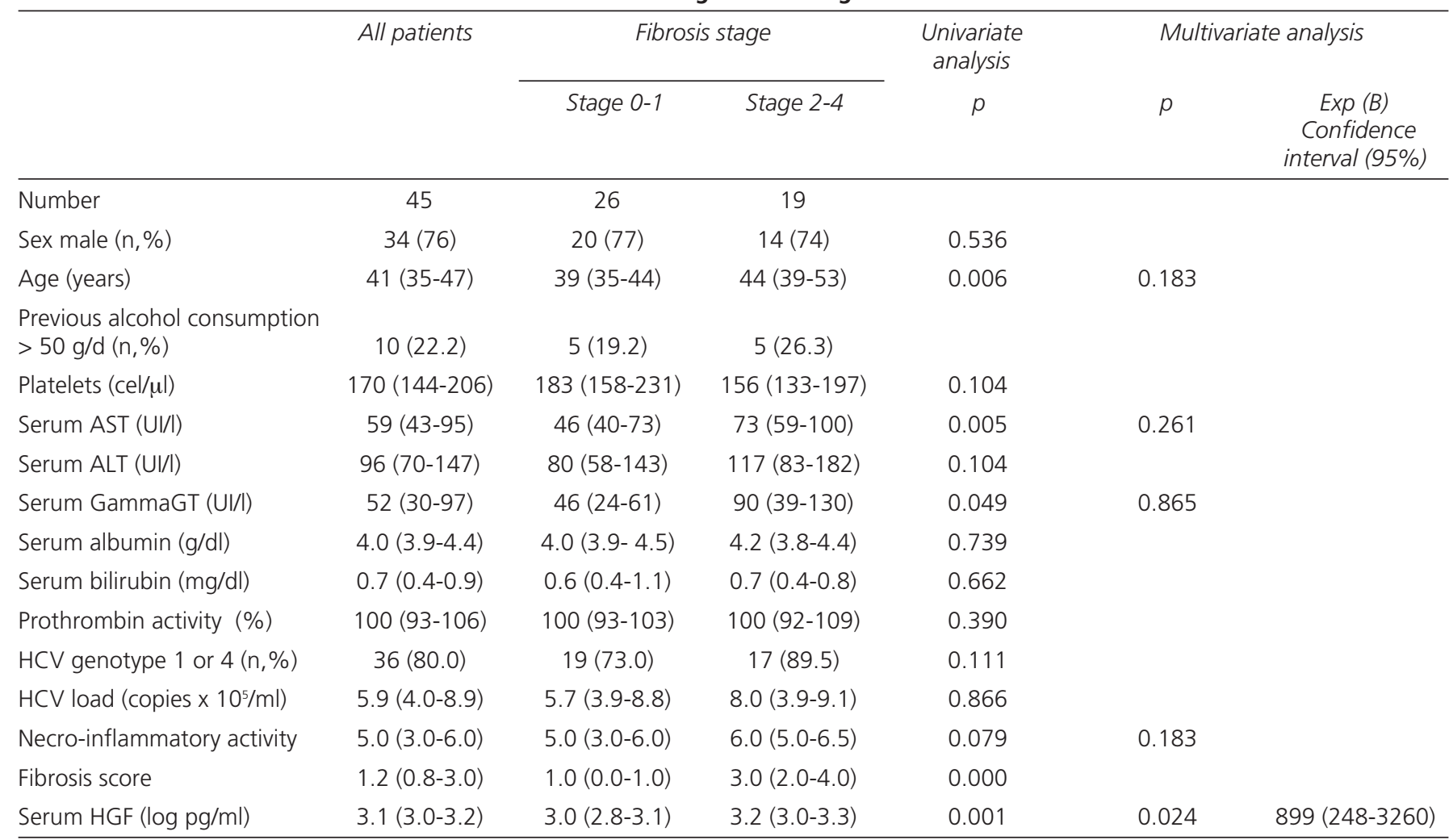




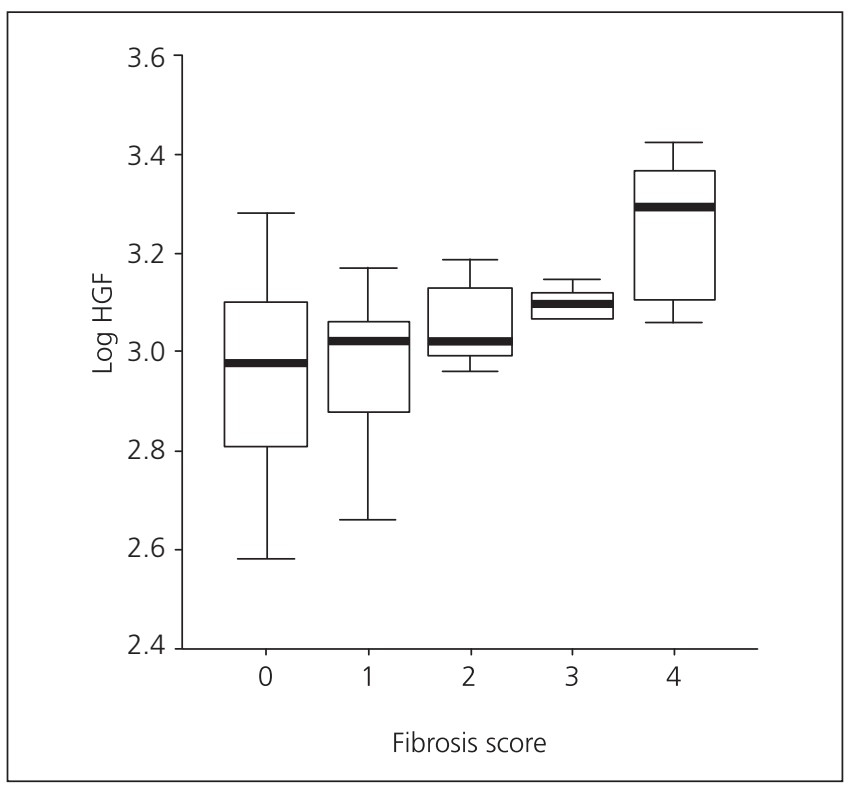

Fig. 1. Serum concentrations of hepatocyte growth factor (HGF) (expressed as $\log 10$ of concentration in $\mathrm{pg} / \mathrm{ml}$ ) in each one of the fibrosis stage.

\section{Evolution after anti-HCV therapy}

A group of 25 patients was treated against HCV infection with interferon and ribavirin. Twenty patients $(80 \%)$ received treatment with standard interferon alpha $2 \mathrm{a}-2 \mathrm{~b}$ at a dose of 3 millions thrice weekly, and five patients (20\%) with pegylated interferon alpha at a dose of $180 \mu \mathrm{g}$ subcutaneously each week.

In function of the response to the treatment, patients were classified in responders (10 cases, $40.0 \%)$, relapsers ( 3 cases, $12.0 \%)$ and non-responders (12 cases, $48.0 \%$ ). With the objective of analysing the evolution of serum HGF concentration during the treatment, pa- tients were grouped in those with complete response to therapy (responders) and those without it (non-responders and relapsers). Those patients with a complete response to treatment had a favourable genotype with significant lower serum levels of ferritin and $\mathrm{HCV}$ load, regarding non-responders. In both groups, HGF levels were analysed at baseline, at the end of the treatment and, in responders, after 6 months of followup. In responder group, HGF levels at baseline, at the end of the therapy, and 6 months of follow-up, were $3.01(2.92-3.09), 3.02(2.79-3.17)$ and 2.93 (2.793.046) $\mathrm{Log} \mathrm{pg} / \mathrm{ml}$, respectively. At baseline and at the end of the treatment in non-responder group, HGF levels were 2.96 (2.58-3.17) and 2.96 (2.69-3.33), respectively. In both groups, levels of HGF did not modify at the end of antiviral treatment and, at baseline and at the end of treatment, concentrations of HGF in patients with and without complete response to therapy was similar $(\mathrm{p}>0.05)$.

\section{DISCUSSION}

HGF, formerly identified and cloned as a potent mitogen for hepatocytes, shows also anti-apoptotic, angiogenic, and immunoregulatory activities (22). In this work, we had hypothesised that serum HGF concentrations could reflect the repairing mechanisms indissolublely associated to liver injury.

The major sources of HGF in the liver are the hepatic stellate cells (22) (HSC), which are identified as the principal collagen-producing cells in the liver, and consequently believed to be the crucial cell type in the development of hepatic fibrosis (23). In an autocrine or paracrine action, HGF suppresses the expression of collagen in animal models (24). This anti-fibrotic effect appeared to be the discontinuation of TGF- $\beta 1$ expression (the most potent fibrogenic precursor to date),



Fig. 2. Area under receiver operating characteristics curve (AUROC) of the models aimed at discriminating significant fibrosis. A. Forns et al. model. B. Wai et al. model. C. Model based on log serum hepatocyte growth factor (HGF) concentrations. Values of the AUROC and $95 \%$ confidence interval are indicated in each case. 
resulting in inhibition of proliferation and activation of HSC (25). Besides, HGF seem to block collagen I and IV synthesis (26) and to induce collagenase activity (27) in HSC. Then, it could be hypothesized that HSC, in response to a persistent tissue injury, try to repair the liver lesion both by increased deposition and altered composition of ECM and by HGF expression, able to induce hepatocyte regeneration and down-regulate an excessive collagen secretion. Therefore, detection in our work of increased serum levels of HGF in patients with $\mathrm{CHC}$ must be considered as a reactive, and possibly, compensatory mechanism implicated in liver repair. This theory is also supported by the increased values in those patients with higher fibrosis stages. In fact, a correlation was found between HGF values and fibrosis score. Moreover, the AUROC obtained in our sample using the serum HGF concentration as a noninvasive index to predict liver fibrosis, was similar to those of the previously validated models of Forns et al. and Wai et al. Obviously, we have to confirm our date in a validation group in order to demonstrate its application in clinical practice. That is to say, according to the data provided in this study, HGF could be a useful serum marker of clinically significant fibrosis in patients with $\mathrm{CHC}$. The relevance, mainly physiological but also prognostic of HGF should be considered.

Nowadays liver fibrosis is considered as a dynamic process, which could be stopped, reduced, even reversed, by antifibrotic therapies. IFN- $\alpha$ is a multi-functional cytokine that could, not only prevent the formation of hepatic fibrosis, but also degrade the fibrotic tissues by inhibiting the TGF- $\beta 1$ production (HGF, as well), decreasing the HSC activation and stimulating its apoptosis (28). So, treatment of $\mathrm{CHC}$ with interferon and ribavirin, in addition to resolve the HCV infection in $40-60 \%$ of the cases, improves the METAVIR score of fibrosis in 0.88 units in patients who have sustained response (29) and reverses almost the $50 \%$ of the cirrhosis (30). Up to now, only a few works are available to clarify the relationship between HGF and therapy for hepatitis C $(15,31)$. In this study, HGF levels were not useful to estimate the efficacy of IFN therapy.

In conclusion, HGF, a glycoprotein synthesized by hepatic stellate cells, correlates with fibrosis score in patients with CHC. Its serum levels, which could be useful, if are validated, as non-invasive index of liver fibrosis, but are insensitive to monitor the changes induced by anti-VHC therapy.

\section{REFERENCES}

1. Valiente N, D'Andrea A, Corta S, Lechner F, Klenerman P, Nuti S, et al. Life, activation and death of intrahepatic lymphocytes in chronic hepatitis C. Immunol Rev 2000; 174: 77-89.

2. Winwood PJ, Arthur MJ. Kupffer cells: their activation and role in animal models of liver injury and human liver disease. Semin Liver
Dis 1993; 13: 50-9.

3. Bataller R, Brenner DA. Liver fibrosis. J Clin Invest 2005; 115: 209-18.

4. Friedman SL. Liver fibrosis-from bench to bedside. J Hepatol 2003; 38 (Supl. 1): S38-S53.

5. Marín Gabriel JC, Solís Herruzo JA. Predicting liver fibrosis with non-invasive tests-a hope for the future. Rev Esp Enferm Dig 2008; 100: $605-10$

6. Fausto N. Liver regeneration. J Hepatol 2000; 32: 19-31.

7. Zimmermann A. Liver regeneration. Nephrol Dial Transplant 2004; 19 (Supl. 4): iv6-iv10.

8. Poynard T, Bedossa P, Opolon P. Natural history of liver fibrosis progression in patients with chronic hepatitis C. Lancet 1997; 349: 825-32.

9. Xue F, Takahara T, Yata Y, Kuwabara Y, Shinno E, Nonome K, et al. Hepatocyte growth factor gene therapy accelerates regeneration in cirrhotic mouse livers after hepatectomy. Gut 2003; 52: 694-700.

10. Yamagami H, Moriyama M, Tanaka N. Detection of serum and intrahepatic human hepatocyte growth factor in patients with type $\mathrm{C}$ liver diseases. Intervirology 2001; 44: 36-42.

11. Yamagami H, Moriyama M, Matsumura H, Aoki H, Shimizu T, Saito T, et al. Serum concentrations of human hepatocyte growth factor is a useful indicator for predicting the occurrence of hepatocellular carcinomas in $\mathrm{C}$-viral chronic liver diseases. Cancer 2002; 95: 824-34.

12. Okano J, Shiota G, Kawasaki H. Expression of hepatocyte growth factor (HGF) and HGF receptor (c-met) proteins in liver diseases: an immunohistochemical study. Liver 1999; 19: 151-9.

13. Shiota G, Okano J, Kawasaki H, Kawamoto T, Nakamura T. Serum hepatocyte growth factor levels in liver diseases: clinical implications. Hepatology 1995; 21: 106-12.

14. Bilezikci B, Haberal AN, Demirhan B. Hepatocyte growth factor in patients with three different stages of chronic liver disease including hepatocellular carcinoma, cirrhosis and chronic hepatitis: an immunohistochemical study. Can J Gastroenterol 2001; 15: 159-65.

15. Anatol $P$, Robert F, Danuta P. Effect of interferon alpha2b plus ribavirin treatment on selected growth factors in respect to inflammation and fibrosis in chronic hepatitis C. World J Gastroenterol 2005; 11: 1854-8.

16. McHutchison PG, Poynard T. Combination therapy with interferon plus ribavirin for initial treatment of chronic hepatitis C. Semin Liver Dis 1999; 19: 57-65.

17. Bisceglie DI, Hoofnagle JH. Optimal therapy of hepatitis C. Hepatology 2002; 36: S121-S127.

18. Knodell RG, Ishak KG, Black WC, Chen TS, Craig R, Kaplowitz N, et al. Formulation and application of a numerical scoring system for assessing histological activity in asymptomatic chronic active hepatitis. Hepatology 1981; 1: 431-5.

19. Desmet VJ, Gerber M, Hoofnagle JH, Manns M, Scheuer PJ. Classification of chronic hepatitis: diagnosis, grading and staging. Hepatology 1994; 19: 1513-20.

20. Forns X, Ampurdanès S, Llovet JM, et al. Identification of chronic hepatitis $\mathrm{C}$ patients without hepatic fibrosis by a simple predictive model. Hepatology 2002; 36: 986-92.

21. Wai CT, Greeson JK, Fontana RJ, Kalbfleisch JD, Marrero JA, Conjeevaram HS, et al. A simple non-invasive index can predict both significant fibrosis and cirrhosis in patients with chronic hepatitis $\mathrm{C}$. Hepatology 2003; 38: 518-26.

22. Stuart KA, Riordan SM, Lidder S, Crostella L, Willians R, Skouteris GG. Hepatocyte growth factor/scatter factor induced intracellular signalling. Int J Exp Pathol 2000; 81: 17-30.

23. Friedman SL, Roll FJ, Boyles J, Bissell DM. Hepatic lipocytes: the principal collagen-producing cells of normal rat liver. Proc Natl Acad Sci USA 1985; 82: 8681-5.

24. Matsuda Y, Matsumoto K, Yamada A, Ichida T, Asakura H, Komoriya $\mathrm{Y}$, et al. Preventive and therapeutic effects in rats of hepatocyte growth factor infusión on liver fibrosis/cirrhosis. Hepatology 1997; 26: 81-9.

25. Yasuda H, Imai E, Shiota A, Fujise N, Morinaga T, Higashio K. Antifibrogenic effect of a deletion variant of hepatocyte growth factor on liver fibrosis in rats. Hepatology 1996; 24: 636-42.

26. Sato M, Kakubari M, Kawamura M, Sugimoto J, Matsumoto K, Ishii $\mathrm{T}$. The decrease in total collagen fibers in the liver by hepatocyte growth factor after formation of cirrhosis induced by thioacetamide. Biochem Pharmacol 2000; 59: 681-90. 
27. Osaki I, Zhao G, Mizuta T, Ogawa Y, Hara T, Kajihara S, et al. Hepatocyte growth factor induces collagenase (matrix metalloproteinase-1) via the transcription factor Ets-1 in human hepatic stellate cell line. J Hepatol 2002; 36: 169-78.

28. Chang XM, Chang Y, Jia A. Effects of interferon alpha on expression of hepatic stellate cell and transforming growth factor- $\beta 1$ and $\alpha$-smooth muscle actin in rats with hepatic fibrosis. World J Gastroenterol 2005; 11: 2634-6.

29. Shiratori Y, Imazeki F, Moriyama M, Yano M, Arakawa Y, Yokosu$\mathrm{ka} \mathrm{O}$, et al. Histologic improvement of fibrosis in patients with hepa- titis $\mathrm{C}$ who have sustained response to interferon therapy. Ann Intern Med 2000; 132: 512-24.

30. Poynard T, McHutchison J, Manns M, Trepo C, Lindsay K, Goodman $\mathrm{Z}$, et al. Impact of pegylated interferon alfa- $2 \mathrm{~b}$ and ribavirin on liver fibrosis in patients with chronic hepatitis C. Gastroenterology 2002; 122: 1303-13

31. Moriyama M, Matsumura H, Watanabe A, Oshiro S, Aoki H, Shimizo T, et al. Evaluation of serum concentrations of human hepatocyte growth factor during interferon therapy for chronic hepatitis C. Intervirology 2005; 48: 223-9. 